\title{
Front Matter: Volume 6920
}

, "Front Matter: Volume 6920," Proc. SPIE 6920, Medical Imaging 2008: Ultrasonic Imaging and Signal Processing, 692001 (25 March 2008); doi: $10.1117 / 12.798455$

SPIE. Event: Medical Imaging, 2008, San Diego, California, United States 


\title{
PROGRESS IN BIOMEDICAL OPTICS AND IMAGING
}

Vol. 9, No. 37

\section{Medical Imaging 2008}

\section{Ultrasonic Imaging and Signal Processing}

\author{
Stephen A. McAleavey \\ Jan D'hooge \\ Editors
}

17-18 February 2008

San Diego, California, USA

Sponsored by

SPIE

Cooperating Organizations

AAPM-American Association of Physicists in Medicine (USA)

APS-American Physiological Society (USA)

CARS - Computer Assisted Radiology and Surgery (Germany)

IS\&T-The Society for Imaging Science and Technology

MIPS-Medical Image Perception Society (USA)

RSNA-Radiological Society of North America (USA)

SIIM-Society for Imaging Informatics in Medicine (USA)

SMI-The Society for Molecular Imaging

The DICOM Standards Committee (USA)

Published by

SPIE

Volume 6920 
The papers included in this volume were part of the technical conference cited on the cover and title page. Papers were selected and subject to review by the editors and conference program committee. Some conference presentations may not be available for publication. The papers published in these proceedings reflect the work and thoughts of the authors and are published herein as submitted. The publisher is not responsible for the validity of the information or for any outcomes resulting from reliance thereon.

Please use the following format to cite material from this book:

Author(s), "Title of Paper," in Medical Imaging 2008: Ultrasonic Imaging and Signal Processing, edited by Stephen A. McAleavey, Jan D'hooge, Proceedings of SPIE Vol. 6920 (SPIE, Bellingham, WA, 2008) Article CID Number.

ISSN 1605-7422

ISBN 9780819471048

Published by

SPIE

P.O. Box 10, Bellingham, Washington 98227-0010 USA

Telephone +1 3606763290 (Pacific Time) · Fax +1 3606471445

SPIE.org

Copyright (c) 2008, Society of Photo-Optical Instrumentation Engineers.

Copying of material in this book for internal or personal use, or for the internal or personal use of specific clients, beyond the fair use provisions granted by the U.S. Copyright Law is authorized by SPIE subject to payment of copying fees. The Transactional Reporting Service base fee for this volume is $\$ 18.00$ per article (or portion thereof), which should be paid directly to the Copyright Clearance Center (CCC), 222 Rosewood Drive, Danvers, MA 01923. Payment may also be made electronically through CCC Online at copyright.com. Other copying for republication, resale, advertising or promotion, or any form of systematic or multiple reproduction of any material in this book is prohibited except with permission in writing from the publisher. The CCC fee code is 1605 $7422 / 08 / \$ 18.00$.

Printed in the United States of America.

Publication of record for individual papers is online in the SPIE Digital Library.

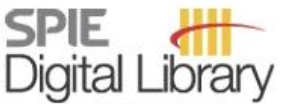

SPIEDigitallibrary.org

Paper Numbering: Proceedings of SPIE follow an e-First publication model, with papers published first online and then in print and on CD-ROM. Papers are published as they are submitted and meet publication criteria. A unique, consistent, permanent citation identifier (CID) number is assigned to each article at the time of the first publication. Utilization of CIDs allows articles to be fully citable as soon they are published online, and connects the same identifier to all online, print, and electronic versions of the publication. SPIE uses a six-digit CID article numbering system in which:

- The first four digits correspond to the SPIE volume number.

- The last two digits indicate publication order within the volume using a Base 36 numbering system employing both numerals and letters. These two-number sets start with 00, 01, 02, 03, 04, $05,06,07,08,09,0 \mathrm{~A}, 0 \mathrm{~B} \ldots \mathrm{.0Z}$, followed by 10-1Z, 20-2Z, etc.

The CID number appears on each page of the manuscript. The complete citation is used on the first page, and an abbreviated version on subsequent pages. Numbers in the index correspond to the last two digits of the six-digit CID number. 


\section{Contents}

ix Conference Committee

xi In Memoriam: Sam Dwyer (1932-2008)

\section{SESSION 1 BEAMFORMING/IMAGE FORMATION I}

692002 Beamformer enhancement by post-processing for improved spatial resolution and signalto-noise ratio [6920-01]

K. Owen, D. A. Guenther, W. F. Walker, Univ. of Virginia (USA)

692003 Medical ultrasound digital beamforming on a massively parallel processing array platform [6920-02]

P. Chen, M. Butts, B. Budlong, Ambric, Inc. (USA)

692004 Real-time implementation of the echo signal processing and digital scan conversion for medical ultrasound imaging with a single TMS320C6416 DSP [6920-03]

C. Lee, H.-Y. Sohn, Sogang Univ. (South Korea); D.-H. Han, LG Electronics Inc. (South Korea); T.-K. Song, Sogang Univ. (South Korea)

692005 Projection-reflection ultrasound images using PE-CMOS sensor: a preliminary bone fracture study [6920-04]

S.-C. B. Lo, Georgetown Univ. Medical Ctr. (USA); C.-C. Liu, Georgetown Univ. Medical Ctr. (USA) and Virginia Polytechnic Institute and State Univ. (USA); M. T. Freedman, S.-K. Mun, Georgetown Univ. Medical Ctr. (USA); J. Kula, M. E. Lasser, B. Lasser, Imperium, Inc. (USA); Y. J. Wang, Virginia Polytechnic Institute and State Univ. (USA)

\section{SESSION 2 BEAMFORMING/IMAGE FORMATION II}

692006 An ideal observer approach to beamforming [6920-06]

C. K. Abbey, Univ. of California, Santa Barbara (USA) and Univ. of California, Davis (USA); N. Nguyen, M. F. Insana, Beckman Institute for Advanced Science and Technology, Univ. of Illinois at Urbana-Champaign (USA)

692007 Globally optimized Fourier finite-difference method for ultrasound breast imaging [6920-07] L. Huang, K. M. Hanson, Los Alamos National Lab. (USA); Y. Quan, Stanford Univ. (USA); C. Li, N. Duric, Karmanos Cancer Institute (USA)

692008 Discrete echo signal modeling of ultrasound imaging systems [6920-08] M. Chen, C. Zhang, Nanyang Technological Univ. (Singapore)

692009 Clinical breast imaging using sound-speed reconstructions of ultrasound tomography data [6920-09]

C. Li, N. Duric, Karmanos Cancer Institute (USA); L. Huang, Los Alamos National Lab. (USA) 
6920 OA 3D PSF analysis for arbitrary transducer geometries and SAFT-based image reconstruction [6920-10]

G. F. Schwarzenberg, H. Gemmeke, N. V. Ruiter, Forschungszentrum Karlsruhe (Germany)

\section{SESSION $3 \quad$ FRONTIERS IN ULTRASOUND}

6920 0C Implantable ultrasound devices [6920-13]

D. Vilkomerson, T. Chilipka, J. Bogan, DVX, LLC (USA); J. Blebea, R. Choudry, J. Wang, M. Salvatore, V. Rotella, K. Soundararajan, Temple Univ. (USA)

\section{SESSION 4 CARDIOVASCULAR}

6920 OD Cardiac phase detection in intravascular ultrasound images [6920-15]

M. M. S. Matsumoto, Aeronautics Institute of Technology (Brazil) and Heart Institute (InCor), Hospital das Clínicas, Univ. de São Paulo (Brazil); P. A. Lemos, Heart Institute (InCor), Hospital das Clínicas, Univ. de São Paulo (Brazil); T. Yoneyama, Aeronautics Institute of Technology (Brazil); S. S. Furuie, Heart Institute (InCor), Hospital das Clínicas, Univ. de São Paulo (Brazil)

6920 OE Evaluation of a level set segmentation method for cardiac ultrasound images [6920-16] Y. Yue, H. D. Tagare, Yale Univ. (USA)

6920 OF Detection of artery interfaces: a real-time system and its clinical applications [6920-17] F. Faita, V. Gemignani, E. Bianchini, CNR Institute of Clinical Physiology (Italy); C. Giannarelli, L. Ghiadoni, Univ. of Pisa (Italy); M. Demi, Institute of Clinical Physiology (Italy) and Esaote SpA (Italy)

6920 0G A new fringeline-tracking approach for color Doppler ultrasound imaging phase unwrapping [6920-19]

A. A. Saad, Univ. of Washington (USA) and Philips Medical Systems (USA); L. G. Shapiro, Univ. of Washington (USA)

$6920 \mathrm{OH} \quad$ Automatic detection of blood versus non-blood regions on intravascular ultrasound (IVUS) images using wavelet packet signatures [6920-20]

A. Katouzian, Columbia Univ. (USA); B. Baseri, Univ. of Medicine and Dentistry of New Jersey (USA); E. E. Konofagou, A. F. Laine, Columbia Univ. (USA)

\section{SESSION $5 \quad$ IMAGE PROCESSING}

$6920 \mathrm{Ol} \quad$ Adaptive spatial compounding for improving ultrasound images of the epidural space on human subjects [6920-21]

D. Tran, K.-W. Hor, A. Kamani, Univ. of British Columbia (Canada); V. Lessoway, BC Women's Hospital and Health Ctr. (Canada); R. N. Rohling, Univ. of British Columbia (Canada)

6920 J Measuring shape complexity of breast lesions on ultrasound images [6920-22]

W. Yang, S. Zhang, Y. Chen, Shanghai Jiao Tong Univ. (China); W. Li, Y. Chen, Shanghai Sixth People's Hospital, Shanghai Jiao Tong Univ. (China) 
6920 OK Image-based method for in-vivo freehand ultrasound calibration [6920-23]

W. Wein, A. Khamene, Siemens Corporate Research (USA)

$6920 \mathrm{OL}$ Spatial compounding for rotating linear probe in the presence of parameter error using image registration [6920-25]

M. H. Choi, Kangwon National Univ. (South Korea); M.-H. Bae, Hallym Univ. (South Korea);

R. Y. Yoon, Medison Co., Ltd. (South Korea)

SESSION 6 TISSUE CHARACTERIZATION

6920 ON Lamb waves detection in a bovine cortical tibia using a scanning laser vibrometry

[6920-27]

M. Hapsara, D. D. Illiescu, Univ. of Warwick (United Kingdom)

$692000 \quad$ Multi-modal breast imaging with ultrasound tomography [6920-28]

N. Duric, C. Li, P. Littrup, C. Glide-Hurst, Karmanos Cancer Institute, Wayne State Univ. (USA);

L. Huang, Los Alamos National Lab. (USA); J. Lupinacci, S. Schmidt, O. Rama, L. Bey-Knight,

Y. XU, Karmanos Cancer Institute, Wayne State Univ. (USA)

6920 OP A novel software-based technique for quantifying placental calcifications and infarctions from ultrasound [6920-29]

J. T. Ryan, Univ. College Dublin (Ireland); F. McAuliffe, M. Higgins, Univ. College Dublin (Ireland) and National Maternity Hospital (Ireland); M. Stanton, P. Brennan, Univ. College Dublin (Ireland)

$69200 Q \quad$ A novel ultrasonic method for measuring breast density and breast cancer risk [6920-30] C. K. Glide-Hurst, William Beaumont Hospital (USA); N. Duric, P. J. Littrup, Karmanos Cancer Institute (USA)

\section{SESSION 7 ELASTOGRAPHY}

6920 OR Estimation of 3D cardiac deformation using spatio-temporal elastic registration of nonscanconverted ultrasound data [6920-31]

A. Elen, D. Loeckx, H. F. Choi, H. Gao, P. Claus, F. Maes, P. Suetens, J. D'hooge, Katholieke Univ. Leuven (Belgium)

6920 OS Real-time visualization of pulsatile tissue-motion in B-mode ultrasonogram for assistance in bedside diagnosis of ischemic diseases of neonatal cranium [6920-32] M. Fukuzawa, M. Yamada, N. Nakamori, Kyoto Institute of Technology (Japan); Y. Kitsunezuka, Saiseikai Hyogo-ken Hospital (Japan)

6920 OU Image-based speckle tracking for tissue motion characterization in a deformable cardiovascular phantom [6920-34]

R. Chan, R. Manzke, S. Dalal, D. Stanton, Philips Research North America (USA); P. Chang, S. Settlemier, I. Salgo, Philips Medical Systems (USA); F. Tournoux, Massachusetts General Hospital (USA) and Harvard Medical School (USA) 
6920 OV IVUS catheter motion: implications for ultrasonic speckle and correction in IVUS palpography [6920-35]

M. G. Danilouchkine, F. Mastik, Erasmus Medical Ctr. (Netherlands); A. F. W. van der Steen, Erasmus Medical Ctr. (Netherlands) and Interuniversity Cardiology Institute of the Netherlands (Netherlands)

6920 OW Strain index: a new visualizing parameter for US elastography [6920-36]

D. Sosa-Cabrera, Univ. of Las Palmas de Gran Canaria (Spain); R. de Luis-García, A. Tristán-Vega, C. Alberola-López, Univ. of Valladolid (Spain); J. Ruiz-Alzola, Canarian Agency for R\&D and Information Technologies (Spain) and Univ. of Las Palmas de Gran Canaria (Spain)

6920 0X A new approach to elastography using a modified demons registration algorithm [6920-37] D. Sosa-Cabrera, Univ. of Las Palmas de Gran Canaria (Spain); A. Tristan-Vega, G. Vegas-Sanchez-Ferrero, Univ. of Valladolid (Spain); J. Gonzalez-Fernandez, L. Gomez-Deniz, Univ. of Las Palmas de Gran Canaria (Spain); C. Alberla-Lopez, Univ. of Valladolid (Spain); J. Ruiz-Alzola, Canarian Agency for R\&D and Information Technologies (Spain) and Univ. of Las Palmas de Gran Canaria (Spain)

\section{POSTER SESSION}

$69200 Z$ Software implementation of ultrasound beamforming using ADSP-TS201 DSPs [6920-40] H.-Y. Sohn, S. Seo, J. Kim, T.-K. Song, Sogang Univ. (South Korea)

692010 High throughput SAFT for an experimental USCT system as MATLAB implementation with use of SIMD CPU instructions [6920-41]

M. Zapf, G. F. Schwarzenberg, N. V. Ruiter, Forschungszentrum Karlsruhe (Germany)

692011 A method to design an optimum pair of transmit and receive periodic sparse arrays [6920-42]

G.-D. Kim, T.-K. Song, Sogang Univ. (South Korea)

692012 Photoacoustic 3D visualization of tumor angiogenesis [6920-45]

G. A. ten Brinke, R. G. M. Kolkman, C. H. Slump, W. Steenbergen, Univ. Twente (Netherlands)

692013 Imaging of acoustic attenuation and speed of sound maps using photoacoustic measurements (Cum Laude Poster Award) [6920-46]

R. G. H. Willemink, S. Manohar, Univ. Twente (Netherlands); Y. Purwar, Indian Institute of Technology Madras (India); C. H. Slump, F. van der Heijden, T. G. van Leeuwen, Univ. Twente (Netherlands)

692014 A study of 3-way image fusion for characterizing acoustic properties of breast tissue [6920-48]

Y. XU, N. Duric, C. Li, Karmanos Cancer Institute (USA); J. Lupinacci, Univ. of Michigan (USA); S. Schmidt, Karmanos Cancer Institute (USA); C. Glide-Hurst, William Beaumont Hospital (USA)

692015 Comparison of ultrasound attenuation tomography methods for breast imaging [6920-49] C. Li, N. Duric, Karmanos Cancer Institute (USA); L. Huang, Los Alamos National Lab. (USA) 
692016 Simulation of microbubble response to ambient pressure changes [6920-51]

K. S. Andersen, J. A. Jensen, Technical Univ. of Denmark (Denmark)

692017 Harmonic quadrature demodulation for extracting the envelope of the second harmonic component [6920-52]

S.-M. Kim, J.-H. Song, T.-K. Song, Sogang Univ. (South Korea)

692018 Measurement of thermally ablated lesions in sonoelastographic images using level set methods (Honorable Mention Poster Award) [6920-53]

B. Castaneda, Univ. of Rochester (USA); J. G. Tamez-Pena, VirtualScopics, Inc. (USA);

M. Zhang, K. Hoyt, Univ. of Rochester (USA); K. Bylund, J. Christensen, W. Saad, J. Strang,

D. J. Rubens, Univ. of Rochester Medical Ctr. (USA); K. J. Parker, Univ. of Rochester (USA)

Author Index 
Downloaded From: https://www.spiedigitallibrary.org/conference-proceedings-of-spie on 26 Apr 2023

Terms of Use: https://www.spiedigitallibrary.org/terms-of-use 


\title{
Conference Committee
}

\author{
Symposium Chairs \\ Milan Sonka, The University of lowa (USA) \\ Armando Manduca, Mayo Clinic (USA) \\ Conference Chairs \\ Stephen A. McAleavey, University of Rochester (USA) \\ Jan D'hooge, Katholieke Universiteit Leuven (Belgium) \\ Program Committee \\ Jeffrey C. Bamber, University of London (United Kingdom) \\ Stanislav Y. Emelianov, The University of Texas at Austin (USA) \\ James F. Greenleaf, Mayo Clinic (USA) \\ Michael F. Insana, University of Illinois at Urbana-Champaign (USA) \\ Jørgen Arendt Jensen, Danmarks Tekniske Universitet (Denmark) \\ Kathryn R. Nightingale, Duke University (USA) \\ K. Kirk Shung, University of Southern California (USA) \\ Kai Erik Thomenius, General Electric Company (USA) \\ David H. R. Vilkomerson, DVX LLC (USA) \\ William F. Walker, University of Virginia (USA)
}

Session Chairs

1 Beamforming/lmage Formation I

Stephen A. McAleavey, University of Rochester (USA)

2 Beamforming/lmage Formation II

Stephen A. McAleavey, University of Rochester (USA)

3 Frontiers in Ultrasound

Jan D'hooge, Katholieke Universiteit Leuven (Belgium)

4 Cardiovascular

Michael F. Insana, University of Illinois at Urbana-Champaign (USA)

$5 \quad$ Image Processing

Jan D'hooge, Katholieke Universiteit Leuven (Belgium) 
6 Tissue Characterization

Stephen A. McAleavey, University of Rochester (USA)

$7 \quad$ Elastography

David H. R. Vilkomerson, DVX LLC (USA) 


\section{In Memoriam}

\section{Sam Dwyer}

1932-2008

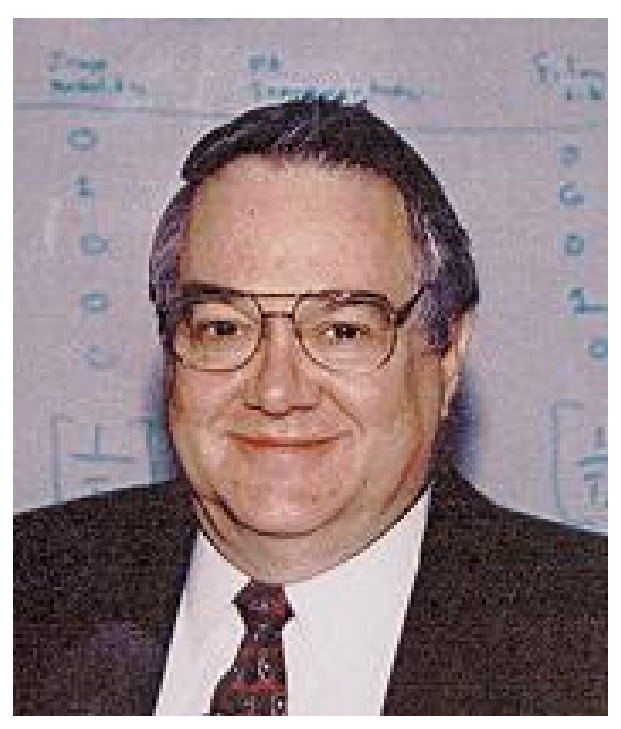

\section{Inspirational planner for SPIE Medical Imaging symposia and chair of 15 conferences from 1983 to 1996}

Sam Dwyer was a leading light in the swift growth of the field of medical imaging. At this 2008 Medical Imaging symposium, several colleagues expressed their appreciation of his professional achievements and the legacy of his contributions.

Andre Duerinckx recalls Sam's first big step into the limelight. "Sam chaired the Second International PACS meeting sponsored by SPIE in 1983. He stepped in when my professional direction shifted and I could not continue. Over the following years Sam became a leading force in the development of this new science and technology as the conferences developed and grew."

"He had an ability to predict important technology trends in medical imaging," says Steven Horii, a long-time SPIE Medical Imaging contributor and past conference chair.

Another past Medical Imaging conference chair with years of experience, Roger Schneider elaborates, "The growth of the initial conferences was phenomenal. They quickly expanded and outgrew several facilities. Topic areas increased. For example, we had been dealing with perception in sessions on image statistics. Sam first suggested that the field of perception theory and experiment was expanding so rapidly that it deserved its own conference. We also added conferences on image processing hardware, display, functional imaging, and special topics in ultrasound transducers."

"Sam was a true pioneer in our field," continues Schneider. "He was one of the first to envision the impact of digital technology on the storage, retrieval, communication, and 
display of medical images, and one of the most active early explorers of the possibilities. He led the PACS conference into the merger with SPIE's image science conference to form the current Medical Imaging Symposium which many consider to be the premiere technical program on medical imaging in the world."

Murray Loew, another past conference chair, adds his observation, "Sam's academic, industrial, and clinical experience provided the perspective that enabled him to set priorities and give advice that helped many of us to make our own contributions. We all benefited greatly from his insights and his practical approach."

Schneider agrees. "Through all, Sam was an excellent partner and leader, calm, gentle yet persuasive, always congenially nudging everyone toward a better future. His ambitions were not for himself, but for the mutual enterprise. He was a very enthusiastic mentor and supporter of students and researchers new to the field without any concern for the possibility that their work might compete with his and was himself a superbly competent contributor."

An example of this is illustrated by John Strauss." Already well accomplished at the time of our first meeting, Sam made the time to take an eager but inexperienced student under his wing. I was not an 'assigned' grad student or research assistant from the University to which he had an obligation. I was a product manager from a vendorpartner. Over the years, from answering technical questions in an understandable way, to providing unassuming career guidance, as well as a sympathetic ear to the challenges of fatherhood or life's many challenges and struggles, Sam was always there for me."

"There are many things about Sam Dwyer that I recall with great fondness, like his always friendly and enthusiastic manner. His advice led me to my years of satisfying work on the ACR-NEMA Committee," adds Horii.

All agree that Sam had many other admirable traits. His wit and sense of humor were legendary, as one of Schneider's favorite memories illustrates. "At the opening of one conference Sam announced, from the podium, that it was the birthday of an important attendee. He said SPIE had requested that the Blue Angels do a flyover-but they already had something scheduled. As a substitute birthday recognition, Sam suggested we take our morning coffee break out on the terrace and watch the landscaping crew circle the flagpole on their riding lawnmowers."

Strauss describes the footprint left by Sam, "While Sam left a legacy through his professional accomplishments, perhaps more lasting is the heritage of leadership he has left behind. He felt it his obligation to pass on his knowledge and wisdom to the next generation, and I was blessed as a recipient. I have and will continue to honor Sam by sharing with those that come after me."

Sam Dwyer was a person of rare quality who will be sorely missed. His name has a permanent place in the annals of medical imaging, and his contributions continue in the flourishing growth of knowledge presented and discussed in the annual Medical Imaging conferences. 